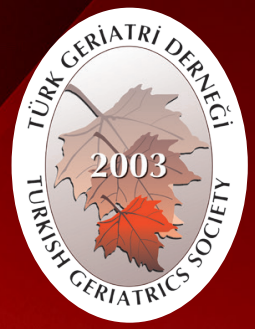

Turkish Journal of Geriatrics DOI: 10.31086/tigeri.2018.67 2018;21 (4):596-606

Hande KAYNAK

CORRESPONDANCE

\section{Hande KAYNAK}

Çankaya University, Psychology,

Ankara, Turkey

Phone: 03122331456

Fax: 03122331029

e-mail: handekaynak@gmail.com

Received: 21/09/2018

Accepted: 11/12/2018

Çankaya University, Psychology, Ankara, Turkey

\section{RESEARCH}

\section{RELATIONS AMONG EMOTIONAL MOOD STATE, PERSONALITY DIMENSIONS AND SOCIAL DESIRABILITY IN OLDER ADULTS}

\section{Abstract}

Introduction: Previous studies have shown that older adults report higher levels of positive affect (PA). Studies in the context of the five-factor model of personality have also noted the age-related changes in personality. However, the possible influence of personality on emotional state needs further investigation in older adulthood. This study examines relations among personality traits, social desirability, and positive/negative affectivity in conjunction with aging.

Materials and Method: A total of 123 volunteers (62 young and 61 older adults) was participated in the study. A cross-design was used with consecutive sampling. All participants had higher education. Participants completed the Positive and Negative Affect Schedule as a measure of emotional state. Thereafter, they rated the degree to which each item described themselves on the Five-Factor Personality Inventory, which measures personality dimensions and social desirability.

Results: Independent t-tests were conducted to compare young and older adults in terms of affectivity and personality. Findings revealed that older adults reported less negative affect (NA) compared with young adults. Older adults scored higher on agreeableness, conscientiousness, and social desirability, whereas young adults scored higher on extraversion and neuroticism. Based on correlational results, neuroticism was negatively correlated with extraversion, social desirability, and PA in older adults. Analyses of variance showed that conscientiousness, neuroticism, and social desirability impacted positive/negative affectivity.

Conclusion: The results indicated that neuroticism proved to be the most important factor on emotional well-being. Older adults low on neuroticism experienced less NA. Furthermore, conscientiousness and social desirability had strong effects on PA indicating that the agerelated differences found in affectivity might not only be attributable to age-related changes in personality, but also partly attributable to age-related increases in social desirability.

Keywords: Aging; Personality; Affect; Emotions; Social desirability

ARAŞTIRMA

\section{YAŞLI YETIŞKINLERDE DUYGUDURUM, KIŞíLIK BOYUTLARI VE SOSYAL ISTENIRLIK ARASINDAKI ILIŞKILER}

\section{Öz}

Giriș: Önceki çalışmalar yaşlıların daha yüksek olumlu duygudurum bildirdiklerini göstermektedir. Beş faktör kişilik modeli bağlamındaki çalışmalar, ayrıca, kişilikte yaşlanmaya bağlı değişiklikleri göstermiştir. Ancak, yaşılıarda kişiliğin duyguduruma olası etkisi hakkında daha fazla araştırmaya ihtiyaç vardır. Mevcut araştırmada, kişilik özellikleri, sosyal istenirlik boyutu ve olumlu/olumsuz duygulanım arasındaki ilişkiler yaşlanmayla birlikte incelenmiștir.

Gereç ve Yöntem: Çalışmaya, 62 genç ve 61 yaşlı olmak üzere 123 gönüllü katılmıştır. Ardışık örneklemle enlemesine desen kullanılmıştır. Tüm katılımcılar yüksek öğrenim düzeyine sahiptir. Katılımcılar duygudurum ölçümleri için Pozitif ve Negatif Duygu Ölçeği'ni doldurmuştur. Sonra, kişilik özelliklerinin ve sosyal istenirlik boyutunun ölçümü için Beş Faktör Kişilik Envanteri'ndeki her maddenin kendilerini ne derece tanımladıklarını derecelendirmişlerdir.

Bulgular: Genç ve yaşlıları olumlu/olumsuz duygulanım ve kişilik açısından karşılaştırmak için bağımsız örneklem t-testleri kullanılmıştır. Yaşılar gençlere göre daha az olumsuz duygulanım rapor etmiştir. Yaşlılar yumuşakbaşılıı, özdenetim ve sosyal istenirlik boyutlarında dahayüksek puanalırken, gençler dışadönüklükve duygusal tutarsızlıkboyutlarında dahayüksek puan almıştır. Korelasyon sonuçlarına göre, yaşlılarda duygusal tutarsızlık; dışadönüklük, sosyal istenirlik ve olumlu duygudurumla negatif ilişkilidir. Olumlu duygudurumsa, dışadönüklük, deneyime açıklık ve sosyal istenirlikle pozitif ilişkilidir. Olumlu/olumsuz duygulanım puanları üzerinde yürütülen varyans analizleri; özdenetim, duygusal tutarsızık ve sosyal istenirlik boyutlarının olumlu/olumsuz duygulanıma etkilerini göstermiştir.

Sonuç: Bulgular, duygusal tutarsızlık boyutunun duygusal iyi oluş üzerinde önemli etken olduğunu göstermiştir. Duygusal tutarsızlık boyutunda düşük puan alan yaşıllar daha az olumsuz duygudurum deneyimlemiştir. Ayrıca, özdenetim ve sosyal istenirlik boyutlarının olumlu duygudurum üzerindeki güçlü etkisi, duygudurumdaki yaşla ilişkili farkların, yalnızca kişilikteki değişikliklere atfedilemeyeceğini, aynı zamanda sosyal istenirlik boyutundaki artışa kısmen atfedilebileceğini göstermiștir.

Anahtar sözcükler: Yaşlanma; Kişilik; Duygulanım; Duygular; Sosyal İstenirlik 


\section{INTRODUCTION}

\section{Personality traits, emotional well-being and aging}

Personality is composed of patterns of thoughts, feelings, behaviors, and moods characteristic of an individual (1). The five-factor model of personality (composed of the Big Five components: extraversion, agreeableness, conscientiousness, neuroticism, and openness to experience) is regarded as a useful and meaningful taxonomy for organizing personality traits (2). These personality traits are captured attention in aging studies $(3,4,5)$. Although personality is generally considered to be stable over time (6), studies have found that agerelated changes do occur in the Big Five dimensions of personality mentioned previously. For instance, openness to experience declines with aging $(4,5,7)$. Older adults prefer to spend their time with close relatives and friends and are less interested in novel opportunities. In contrast, young adults are more open to meeting new people, seeing new places, and learning new information. In a study, when participants were given a hypothetical choice to either spend time with a family member or meet someone new such as a famous author (8), older adults were more likely to select the emotionally close social partner, whereas young adults were more likely to select the social partner who could provide new information. Moreover, due to the absence of work-related social interactions, older adults experience less social stimulation, which impacts their extraversion scores (5). Agreeableness and conscientiousness increase with age (5), whereas neuroticism declines $(3,5)$.

The age-related changes in personality might influence emotional well-being in older adulthood because personality is also an important predictor of emotional well-being (9). It is the emotional dimensions of which are described as positive affect (PA) and negative affect (NA). PA reflects the extent to which a person feels enthusiastic, alert, and active; conversely, NA reflects the degree to which a person experiences contempt, disgust, fear, anger, and guilt (10). In this sense, personality traits may considerably impact people's emotional state because they influence people's sense of their own satisfaction (9).

The subjective evaluation of satisfaction increases across the life span. In a study of participants aged 18 to 94 years, PA appeared to remain constant (11) or increase (12) with increasing age. In contrast, the frequency and duration of NA experienced in daily life decreased with age $(8,11)$. Thus, young adults are more likely to be in a negative mood, whereas older adults appear to experience fewer negative emotions. Similarly, the literature on developmental depression has indicated that older adults are at a lower risk for depression compared with young adults (13).

The age-related changes in affectivity might be evaluated in term of changes in personality. Among the five personality traits, extraversion and neuroticism have the strongest and the most consistent associations with positive (14) and negative affectivity (15), respectively. Individuals who score high on extraversion are usually affectionate, talkative, fun-loving, and passionate (2). Those scoring low on this trait are usually passive and lonely and lack the ability to express their feelings. In line with such reasoning, the correlation between extraversion and positive affectivity becomes especially important among older adults, who may have fewer social opportunities. Researchers have observed that individuals high on extraversion especially experience high levels of positive emotion when socializing with other people $(16,17)$. McCrae and Costa (2) suggested that extraversion leads to PA, agreeableness and conscientiousness results in increased emotional well-being. On the other hand, neuroticism leads to NA (2). Specifically, higher scores on extraversion and agreeableness render people more likely to experience PA, whereas higher neuroticism scores are associated with greater likelihood of experiencing NA $(3,5)$. Hence, it can be concluded that emotional states and personality traits interact with one another. 


\section{Social desirability and aging}

Personality assessments rely on self-reported data. One of the issues with self-reports is the tendency to answer questions in a socially desirable way (18). This type of response bias refers to social desirability and can be provided in specially designed personality inventories as scores, independently from personality dimension scores. Social desirability can also influence measures of individuals' emotional states. It seems that older adults have a tendency to self-report of more satisfaction and happiness (19). Most studies on emotional states have neglected social desirability; however, this factor also plays an important role in explaining personality changes (18) and subjective emotional states in older adults. Although agerelated changes in social desirability are important in explaining emotional well-being, to the best of our knowledge, the current study is among the few ones including a measure of social desirability in aging studies and the only one conducted in the Turkey's aging population.

Although personality provides explanation to the changes in affectivity in older adults, this might be the only one part of the story. For example, since older adults are not usually high on extraversion (5), this trait does not seem to be the main factor of PA. On the other hand, age-related increases in social desirability could provide additional explanation why older adults specifically attain or maintain their positive affectivity. In other words, social desirability which is affected by aging could be another variable and explains why older adults experience positive rather than negative affectivity and maintain high levels of emotional well-being and social harmony. In this regard, the relations between personality dimensions and social desirability need further investigation. In a study (19), when researchers analyzed the effects of age-related social desirability changes on age-related personality changes, they found that there were no significant relationships between age and neuroticism, consciousness and agreeableness, when social desirability was controlled. Thus, although personality seems to be a cause of one's emotional state, social desirability could explain the positive affectivity in older adults. These associations again highlight the importance of considering the manner in which aging and changes in personality and social desirability interactively influence the emotional state.

\section{The present study}

Taking all these into account the present study was designed to examine whether the participants' personality traits, social desirability, and current emotional state are a function of age. First, agerelated changes in affectivity and personality were investigated separately. Secondly, significant correlations were analyzed between personality dimensions, social desirability dimension, and affectivity among older participants, so the present research was extended by also examining the social desirability variable as a function of age. Last, further analysis was intended to assess the effects of age, personality traits, and social desirability on emotional state and determine the dimensions, if any, that play a crucial role in older adults' emotional states.

It was hypothesized that age would be associated with less negative affect, and higher positive affect. It was also predicted that there would be age-related decreases in extraversion, openness to experience, and neuroticism, whereas age would be associated with higher scores on agreeableness, conscientiousness, and social desirability. With regard to the relations between personality and affect, positive affectivity was expected to be associated with extraversion, agreeableness, conscientiousness, and social desirability; on the other hand, negative affectivity was expected to be associated with neuroticism. It was further predicted that older adults high on agreeableness, conscientiousness would experience higher positive affectivity. On the other hand, older adults high on social desirability were expected to be less likely to experience negative affect. Higher neuroticism 
scorers were predicted to experience greater negative affect in older participants.

\section{MATERIALS AND METHOD}

\section{Participants}

The sample consisted of 123 volunteers; 62 young adults [mean age, 20.77 (range 18-24) years, $32 \mathrm{~F}$, $30 \mathrm{M}$ ] and 61 older adults [mean age, 77.62 (range 65-89) years, 36 F, 25 M]. Undergraduate students at Çankaya University and Middle East Technical University (METU) received course credits for participating in the study. The older adult participants were chosen from among the residents of Ankara Nursing Home of Social Security Institution for Civil Servants, and were recruited from social centers and cultural centers for the elderly and mostly from the visitors of Ankara Metropolitan Municipality Women Services. Consecutive sampling method was used to recruit these participants. The two groups were significantly different only in age; no other differences were observed in terms of demographic characteristics such as years of education. The demographical information of the participants is shown in Table 1. All participants gave informed consent to their participation in a method approved by the Çankaya University Ethics Committee.

Table 1. The demographical information of the participants.

\begin{tabular}{|c|c|c|c|}
\hline \multirow{2}{*}{ Age } & Young & $\begin{array}{l}M=20.77 \\
s d=1.56\end{array}$ & \\
\hline & Older & $\begin{array}{l}M=77.62 \\
s d=6.72\end{array}$ & \\
\hline \multirow{2}{*}{ Years of education } & Young & $\begin{array}{l}M=13.31 \\
s d=1.21\end{array}$ & \\
\hline & Older & $\begin{array}{l}M=13.12 \\
s d=2.12\end{array}$ & \\
\hline \multirow{2}{*}{ Gender } & Young & $\begin{array}{c}\text { Female }=32 \\
\text { Male }=30\end{array}$ & $\begin{array}{l}(52 \%) \\
(48 \%)\end{array}$ \\
\hline & Older & $\begin{array}{l}\text { Female }=36 \\
\text { Male }=25\end{array}$ & $\begin{array}{l}(59 \%) \\
(41 \%)\end{array}$ \\
\hline \multirow{2}{*}{ Marital status } & Young & $\begin{array}{l}\text { Married }=0 \\
\text { Single }=62 \\
\text { Widowed/Divorced }=0\end{array}$ & (100\%) \\
\hline & Older & $\begin{array}{l}\text { Married }=15 \\
\text { Single }=5 \\
\text { Widowed/Divorced }=41\end{array}$ & $\begin{array}{l}(25 \%) \\
(8 \%) \\
(67 \%)\end{array}$ \\
\hline \multirow{2}{*}{ Occupation } & Young & $\begin{array}{l}\text { State }=0 \\
\text { Private }=0 \\
\text { Self-employed }=0 \\
\text { Nonworking } / \text { Student }=60\end{array}$ & (100\%) \\
\hline & Older & $\begin{array}{l}\text { State }=2 \\
\text { Private=6 } \\
\text { Self-employed=2 } \\
\text { Nonworking/Retired=51 }\end{array}$ & $\begin{array}{c}(3 \%) \\
(10 \%) \\
(3 \%) \\
(84 \%)\end{array}$ \\
\hline
\end{tabular}

a Notes: M=Mean; sd=Standard deviation 


\section{Materials}

\section{Positive and Negative Affect Schedule}

Participants were asked to complete the Positive and Negative Affect Schedule (PANAS) to assess their current emotional state $(10,20)$. The PANAS is a reliable, valid, and efficient assessment commonly used to measure both the positive and negative affectivity related to emotional well-being. Positive affect and negative affect have emerged as two independent dimensions on this scale in both the United States and various other countries. Watson, Clark, and Tellegen (10) developed the two 10 -item mood scales that comprise the PANAS. The version for Turkish culture was developed by Gençöz (20). The 10 positive (e.g., "interested") and 10 negative (e.g., "guilty") emotional states are mixed together and rated on five-point Likerttype scales. Participants rate their "last week" state on a scale from 1 (very slightly or not at all) to 5 (extremely). Thus, the total score for each affect can range from 10 to 50 .

\section{Five-Factor Personality Inventory}

The Big Five personality variables were assessed using the Five-Factor Personality Inventory (5FPI) (2,21). 5FPI is the most widely used personality test across different cultures and languages (21). The inventory is organized into the Big Five personality dimensions of extraversion, agreeableness, conscientiousness, neuroticism, and openness to experience (2). A version of the inventory suitable for Turkish culture was developed by Somer, Korkmaz, and Tatar (21). The Turkish 5FPI is an 85-item questionnaire that assesses five domains of normal personality functioning and also social desirability dimension. Items are answered on a five-point Likert scale ranging from "completely agreeable" to "not at all agreeable."

\section{Procedure}

The participants first completed the informed consent form. Participants then completed the self-report questionnaires on demographic characteristics. Next, they completed PANAS; the average time for completion was approximately 5 minutes for young adults and 10 minutes for older adults. Finally, they completed 5FPI (average time: approximately 15 minutes for young adults and 30 minutes for older adults). After a debriefing, they were thanked and dismissed.

\section{RESULTS}

\section{Relation between PANAS scores and age}

Independent t-tests were performed to examine how PANAS scores of the young and older participants differed from each other (Figure 1). The PA scores of young and older participants did not differ significantly, $t(121)=.70, p>.05$. In contrast, young participants experienced greater NA than older participants; this difference was significant, $t(121)=4.03, p=.000$.

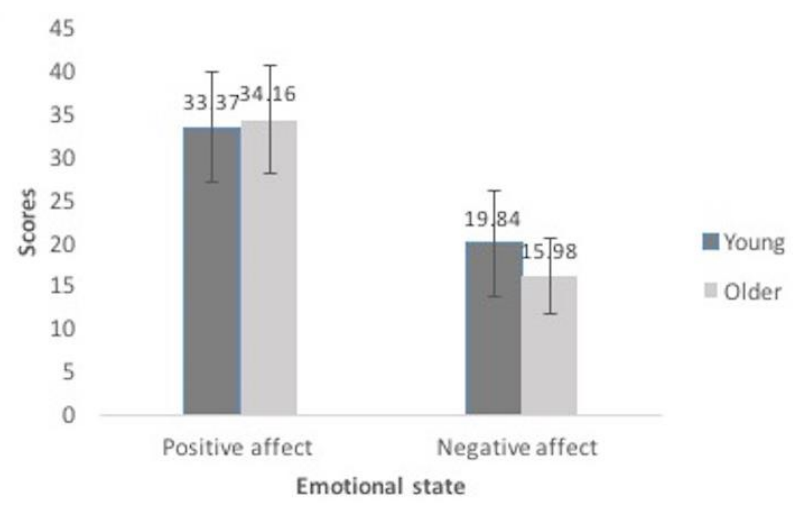

Figure 1. PANAS scores. Error bars represent standard error. 


\section{Relation between personality scores and age}

Independent t-tests were conducted to determine the difference between age groups in terms of the Big Five personality dimensions (Figure 2). Young participants had significantly higher scores on extraversion compared with older participants, $t(121)=2.86, p<.05$. Older participants had significantly higher scores on agreeableness than young participants, $t(121)=2.52, \quad p<.05$. Similarly, older participants had significantly higher scores on conscientiousness compared with young participants, $t(121)=4.60, p<.05$. Young participants scored significantly higher on neuroticism than older participants, $t(121)=2.56, p<.05$. Young participants had higher scores on openness to experience than older participants. However, this difference was not significant $t(121)=1.58, p>05$. Finally, older participants had significantly higher scores on social desirability than young participants, $t(121)=3.94$, $p<.05$.

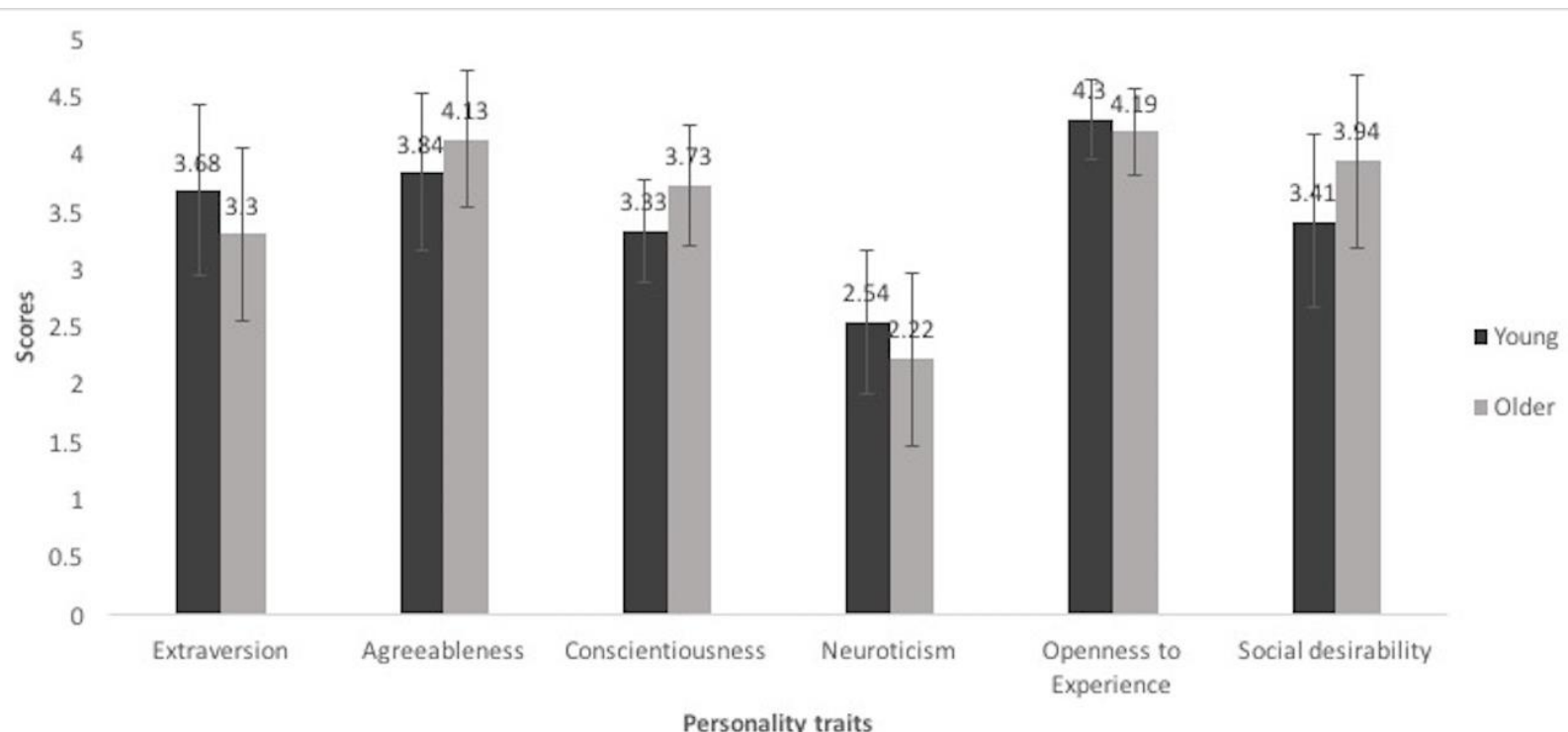

Figure 2. 5FPI and social desirability scores. Error bars represent standard error.

\section{Relations among personality characteristics, social desirability, and PANAS scores}

Pearson correlations were calculated for the personality dimensions, social desirability, and positive and negative affect separately for age groups. Table 2 indicates the correlation matrix among the variables of interest for young participants. Higher scores on neuroticism were associated with lower scores on extraversion $(r=-.34, p<.01)$, conscientiousness $(r=-.22, p<.05)$, and PA $(r=-.49, p<.01)$. The correlation between neuroticism and NA was significant $(r=.40, p<.01)$. Agreeableness was positively correlated with openness to experience $(r=.33, p<.01)$ and social desirability $(r=.39, \quad p<.01)$. PA was positively correlated with conscientiousness $(r=.25, p<.05)$. No other significant correlations between other dimensions of $5 \mathrm{FPI}$ and PANAS were noted among young participants. 
Table 2. Correlations among personality dimensions, social desirability, and positive-negative affect in young and older adults.

\begin{tabular}{|c|c|c|c|c|c|c|c|c|}
\hline $\begin{array}{l}\text { Correlation matrix } \\
\text { Young }\end{array}$ & $\mathrm{E}$ & C & A & $\mathbf{N}$ & OE & so & PA & NA \\
\hline Extraversion & 1 &,- 134 & 011 &,- 341 ** &, 188 &,- 053 &, 167 &,- 043 \\
\hline Conscientiousness & & 1 &, 003 &,$- 222^{\star}$ & 061 & ,276* &, $251 *$ & ,020 \\
\hline Agreeableness & & & 1 &,- 107 &, $332 * \star$ &, $388^{\star *}$ &,- 044 &,- 102 \\
\hline Neuroticism & & & & 1 &,- 180 &,- 210 &,$- 493^{\star \star}$ &, $400 * *$ \\
\hline Openness to experience & & & & & 1 &,- 024 & ,063 &,- 026 \\
\hline Social desirability & & & & & & 1 &, 103 &,- 145 \\
\hline Positive affect & & & & & & & 1 &,- 192 \\
\hline Negative affect & & & & & & & & 1 \\
\hline $\begin{array}{l}\text { Correlation matrix } \\
\text { Older }\end{array}$ & $E$ & C & A & $\mathbf{N}$ & OE & so & PA & NA \\
\hline Extraversion & 1 & 019 &,- 120 &,$- 213^{*}$ & 124 &,- 026 &, $398 * \star$ & 019 \\
\hline Conscientiousness & & 1 &, $430 * \star$ &,- 068 & ,234* &, $227^{*}$ & 200 & ,020 \\
\hline Agreeableness & & & 1 &,- 183 & ,098 &, $260 *$ &, 161 &,- 170 \\
\hline Neuroticism & & & & 1 &,- 207 &,$- 376^{\star \star}$ &,$- 375^{\star \star}$ & ,479** \\
\hline Openness to experience & & & & & 1 & 014 &, $330 * *$ &,- 143 \\
\hline Social desirability & & & & & & 1 & ,230* &,- 211 \\
\hline Positive affect & & & & & & & 1 &,- 075 \\
\hline Negative affect & & & & & & & & 1 \\
\hline
\end{tabular}

a Notes: One-tailed; ${ }^{*} p<.05 ;{ }^{* *} p<.01$.

For older participants (Table 2), neuroticism was negatively correlated with extraversion ( $r=-$ $.21, p<.05)$, social desirability $(r=-.38, p<.01)$, and PA $(r=-.38, p<.01)$. In contrast, neuroticism was positively correlated with NA $(r=.48, p<.01)$. Higher scores on conscientiousness were associated with higher scores on agreeableness $(r=.43, p<.01)$, openness to experience $(r=.23, p<.05)$, and social desirability $(r=.23, p<.05)$. Social desirability was positively correlated with agreeableness $(r=.26, p<.05)$. PA was positively correlated with extraversion $(r=.40, p<.01)$, openness to experience $(r=.33, p<.01)$, and social desirability $(r=.23, p<.05)$. No significant correlations were observed between other dimensions of 5FPI and PANAS among older participants.

\section{Effects of age and personality on PANAS scores}

All participants were grouped as either "low" or "high" on each of the five personality dimensions and on social desirability, splitting the groups at the median. Medians were separately computed for each age group to eliminate the age effect. For example, the 31 young participants scoring 3.75 or above on extraversion were included in the "high extraversion" group, and 31 participants scoring below 3.75 were included in "low extraversion" group. 
As preliminary analyses revealed no effects for gender, it was not included as a factor in the analyses reported below. Table 3 summarizes the results of a 2 (age: young and older) $\times 2$ (personality dimensions: high and low) univariate analysis of variance (ANOVA), and of a 2 (age) $\times 2$ (Social desirability) univariate ANOVA with PA and NA scores as the dependent measures.

Table 3. Summary of ANOVA Results on PA and NA scores.

\begin{tabular}{|c|c|c|c|c|c|c|}
\hline \multirow[b]{2}{*}{ Source } & \multicolumn{3}{|c|}{ PA scores } & \multicolumn{3}{|c|}{ NA Scores } \\
\hline & $F(1,119)$ & $p$ & $\eta \rho^{2}$ & $F(1,119)$ & $p$ & $\eta \rho^{2}$ \\
\hline Age & .26 & .61 & .00 & 16.32 & .000 & .12 \\
\hline Extraversion & 2.50 & .12 & .02 & .36 & .55 & .00 \\
\hline AgexE & .19 & .69 & .00 & .02 & .89 & .00 \\
\hline Age & .47 & .49 & .00 & 16.03 & .000 & .12 \\
\hline Conscientiousness & 6.11 & .02 & .05 & .00 & .94 & .00 \\
\hline Age $\times C$ & .04 & .84 & .00 & .58 & .45 & .01 \\
\hline Age & .37 & .54 & .00 & 16.17 & .000 & .12 \\
\hline Agreeableness & 2.77 & .09 & .02 & 2.06 & .11 & .02 \\
\hline Age $\times A$ & .65 & .42 & .01 & .17 & 69 & .00 \\
\hline Age & .67 & .42 & .01 & 17.43 & .000 & .13 \\
\hline Neuroticism & 15.68 & .000 & .12 & 8.95 & .003 & .07 \\
\hline Age $\times N$ & .29 & .59 & .00 & .12 & .74 & .00 \\
\hline Age & .50 & .48 & .00 & 15.98 & .000 & .12 \\
\hline Openness to experience & 1.51 & .22 & .01 & .20 & .65 & .00 \\
\hline Age $\times O E$ & 2.59 & .11 & .02 & 2.70 & .10 & .02 \\
\hline Age & .42 & .52 & .00 & 16.72 & .000 & .12 \\
\hline Social desirability & 4.33 & .04 & .04 & 2.94 & .09 & .02 \\
\hline Age $\times$ SO & 1.52 & .22 & .01 & .26 & .61 & .00 \\
\hline
\end{tabular}

a Notes: Effect size $=$ partial $\eta \rho^{2}$

$\mathrm{E}=$ Extraversion; $\mathrm{C}=$ Conscientiousness; $\mathrm{A}=$ Agreeableness; $\mathrm{N}=$ Neuroticism; $\mathrm{OE}=$ Openness to experience; $\mathrm{SO}=$ Social desirability.

\section{Analyses of PA}

The results indicated the main effects of conscientiousness $\left(F_{(1,119)}=6.11, p<.05, \eta \rho^{2}=.05\right)$, neuroticism $\left(F_{(1,119)}=15.68, \quad p=.000, \eta \rho^{2}=.12\right)$, and social desirability $\left(F_{(1,119)}=4.33, p<.05\right.$, $\left.\eta \rho^{2}=.04\right)$ on PA. The main effects of extraversion, agreeableness and openness to experience were not significant. Furthermore, no main effect of age on PA was observed. Two-way interactions on PA did not reach conventional levels of significance; however, PA scores of older participants high on social desirability were marginally $(p=.09)$ higher than those of participants low on social desirability.

\section{Analyses of NA}

The results indicated the main effects of neuroticism $\left(F_{(1,119)}=8.95, p<.01, \eta \rho^{2}=.07\right)$ on NA. The main effects of extraversion, agreeableness, conscientiousness, openness to experience, and social desirability were not significant. The main effect of age $\left(F_{(1,119)}=16.32, p=.000, \eta \rho^{2}=.12\right)$ on $N A$ was observed, indicating that older participants experienced less NA than young participants. Twoway interactions on NA did not reach conventional levels of significance. 


\section{DISCUSSION}

This study considered whether the major personality dimensions and social desirability are associated with the emotional state of older adults. We expected specific personality traits (such as neuroticism, agreeableness, conscientiousness) and social desirability scores to be the potentially important causes of emotional well-being in older adults. The findings were partially consistent with these expectations.

First, it was examined whether there is an agerelated difference in affectivity, which was assessed by measuring the positive and negative affect. As in prior studies $(11,13)$, the results showed older adults were less likely to report NA. Although older adults reported higher PA on the PANAS, the age groups did not differ significantly with respect to PA scores. Since advancing age is often associated with increasing satisfaction (12), findings of this study did not provide support for such positive affectivity. Rather, it has been showed that older adults did not feel happier than young adults, but they experienced less NA compared with young adults. Alternatively, it could simply mean that that older adults increase their daily satisfaction level by reducing their NA.

Secondly, it was investigated how the personality changes with aging. In the present study, the personality trait scores showed a noticeable difference between age groups. Older adults' agreeableness and conscientiousness scores were significantly higher than those of young adults. As hypothesized, older adults had lower scores on extraversion and neuroticism. On the other hand, age was not found to be a cause of openness to experience. Although there was no significant difference between young and older adults in terms of openness to experience scores, older adults scored less on this dimension. These findings are consistent with research suggesting that personality is not stable over time but changes as a function of age $(3,5,7)$.

Thirdly, the present findings revealed strong relations overall between personality, social desirability, and affect in older adults. In this sense, results supported previous findings that personality is an important correlate of emotional state. In general, older adults' PA scores exhibited strong correlations with most of the personality dimensions. Extraversion and openness to experience were associated with increased levels of PA. It is not surprising that the active and exciting life of extroverts is reflected emotionally in the experience of positive emotions $(2,3)$. The positive relationship detected between openness to experience and PA among the elderly is also reasonable because high scorers on openness to experience are more likely to experience a diversity of emotions and prefer variety $(2,7)$. While PA was negatively correlated with neuroticism, NA was found to be positively correlated with neuroticism. Since neuroticism is highly correlated with anxiety, highly neurotic individuals are easily worried, they are more likely to experience negative affect (2). Moreover, the significant correlations between the dimensions of the 5FPI and PANAS showed that these two scales were strongly interrelated. Another variable assessed in the personality inventory was social desirability. There is a consensus in studies on aging that older adults are more likely to present themselves overly favorably (18). Consistent with some previous findings $(18,19)$, the results showed that older adults' social desirability scores were significantly higher than those of young adults. Results of correlation analyses also revealed that social desirability was positively correlated with agreeableness, conscientiousness, and positive affect; whereas social desirability was negatively correlated with neuroticism. 
Last, it was also investigated how age and personality traits impacted emotional states, which are PA and NA. Results showed that older adults scoring highly on neuroticism were more prone to experiencing high NA. Lower scorers of neuroticism were more prone to be experiencing greater PA. Results supported the McCrae and Costa's (2) description of neuroticism, that is the proneness of the individual to experience unpleasant and disturbing emotions. In the present study among five personality traits, neuroticism was found to be the most significant cause of emotional well-being by having influence on both negative and positive affectivity. In addition to neuroticism, conscientiousness has found to influence emotional state. That is, participants scoring highly on conscientiousness were more likely to report PA. Since individuals high on conscientiousness have the tendency to maintain stability within themselves, this tendency could be reflected in the emotional state. Contrary to the findings of Terracciano et al.'s study (5), we did not find a significant effect of agreeableness on positive affectivity although the participants high on agreeableness did report marginally higher PA than the participants low on agreeableness.

In addition to personality dimensions, social desirability was one of the potential variables which could affect emotional state. It was found that participants scoring highly on social desirability were more prone to experiencing high PA. Since social desirability was also found to be associated with increased levels of PA in the previous correlational analyses, such response bias seemed to enhance emotional well-being in older adults.

Overall, even though we did not replicate the previously reported the positive affectivity in older adults, the findings have suggested that older adults do not have significantly higher levels of positive affect than young adults; indeed, they have reliably lower levels of negative effect. Furthermore, another important finding is that conscientiousness and social desirability had strong effects on PA indicating that the agerelated differences found in affectivity might not only be attributable to age-related changes in personality, but also partly attributable to agerelated increases in social desirability.

One limitation is that reliability and validity studies concerning the PANAS have been conducted only with younger populations. Clearly, this confirmation of the PANAS should be extended to older adulthood. Furthermore, the study's findings regarding interactions among age, personality traits, and positive/negative affect were cross-sectional. Future research should also consider longitudinal work. The findings of age-related differences in personality, social desirability and affect could be attributable to the emotional regulation strategies which are used by older adults with conscious effort. It was stated that they have greater capacity for emotion regulation, which gives them the ability and motivation to seek positive emotional experiences more effectively and avoid negative experiences (22). Thus, in further studies, it seems to be important to add emotional regulation as a variable for disentangling age-related factors in personality and positive/negative affectivity. Nevertheless, the present findings provide a solid justification for examining how the relations between personality and emotional affect may vary between young and older adults.

\section{ACKNOWLEDGEMENTS}

Thanks to the anonymous reviewers for their attentive reading and constructive feedback on the earlier version of this paper. 


\section{REFERENCES}

1. Charles S, Carstensen LL. Social and emotional aging. Annu Rev Psychol 2010;61:383-409. (PMID:19575618).

2. Funder DC. Personality. Annu Rev Psychol 2001;52:197-221. (PMID:11148304).

3. Fung HH, Carstensen LL, Lutz AM. Influence of time on social preferences: implications for life-span development. Psychol Aging 1999;14(4):595-604. (PMID:10632147).

4. G Matthews, IJ Deary, MC Whiteman. Personality Across the Life Span, In:Gerald Matthews, Ian J Deary, Martha C Whiteman (Eds). Personality Traits. 3rd edition, Cambridge University Press, Cambridge 2009, pp 63-84.

5. Gençöz T. Positive and negative affect schedule: a study of validity and reliability. Turk J Psychol 2000;15(46):19-28. (in Turkish).

6. Haigh EAP, Bogucki OE, Sigmon ST, Blazer DG. Depression among older adults: a 20-year update on five common myths and misconceptions. Am J Geriatr Psychiatry 2018;26(1):107-22. (PMID:28735658).

7. Lucas RE, Baird BM. Extraversion and emotional reactivity. J Pers Soc Psychol 2004;86(3):473-85. (PMID:15008650).

8. Lucas RE, Fujita F. Factors influencing the relation between extraversion and pleasant affect. J Pers Soc Psychol 2000;79(6):1039-56. (PMID:11138753).

9. McCrae RR, Costa PT Jr. The structure of interpersonal traits: Wiggins's circumplex and the five-factor model. J Pers Soc Psychol 1989;56(4):58695. (PMID:2709308).

10. Mroczek DK. Age and emotion in adulthood. Curr Dir Psychol Sci 2001;10:87-90. [Internet] Available from: https://www.jstor.org/stable/20182706. Accessed: 25.6.2018.

11. Munoz E, Stawski RS, Sliwinski MJ, Smyth JM, MacDonald SWS. The ups and downs of cognitive function: neuroticism and negative affect drive performance inconsistency. J Gerontol B Psychol Sci Soc Sci 2018;gby032. (PMID:29590450).

12. O Somer, M Korkmaz, A Tatar. Development of Five Factor Personality Inventory, In:Oya Somer, Mediha Korkmaz, Arkun Tatar (Eds). From Theory to Practice Five-Factor Personality Model and Five-Factor Personality Inventory. Ege University, Izmir 2004, pp 45-66. (in Turkish).
13. Roberts BW, DelVecchio WF. The rank-order consistency of personality traits from childhood to old age: a quantitative review of longitudinal studies. Psychol Bull 2000;126(1):3-25. (PMID:10668348).

14. Schwaba T, Luhmann M, Denissen JJA, Chung JM, Bleidorn W. Openness to experience and cultureopenness transactions across the lifespan. J Pers Soc Psychol 2018;115(1);118-36. (PMID:28557472).

15. Şimşek, ÖF. Higher order structure of personality and mental health: does general affectivity matter? J Pers Assess 2014;96(2):226-36. (PMID:24066739).

16. Smillie LD, DeYoung CG, Hall PJ. Clarifying the relation between extraversion and positive affect. $J$ Pers 2015;83(5):564-74. (PMID:25234441).

17. Soubelet A, Salthouse, TA. Influence of social desirability on age differences in self-reports of mood and personality. J Pers 2011;79(4):741-62. (PMID:21682727).

18. Terracciano A, McCrae RR, Brant, LJ, Costa PT Jr. Hierarchical linear modeling analyses of the NEO-PI-R scales in the Baltimore Longitudinal Study of Aging. Psychol Aging 2005;20(3):493-506. (PMID:16248708).

19. Vigil-Colet A, Morales-Vives F, Lorenzo-Seva U. How social desirability and acquiescence affect the agepersonality relationship. Psicothema. 2013;25(3):3428. (PMID:23910749).

20. Watson D, Clark LA, Tellegen A. Development and validation of brief measures of positive and negative affect: the PANAS scales. J Pers Soc Psychol 1988;54(6):1063-70. (PMID:3397865).

21. Williams LM, Brown KJ, Palmer D, et al. The mellow years? Neural basis of improving emotional stability over age. J Neurosci 2006;26(24):6422-30. (PMID:16775129).

22. Wortman J, Lucas RE, Donnellan MB. Stability and change in the big five personality domains: evidence from a longitudinal study of australians. Psychol Aging 2012;27(4):867-74. (PMID:22775362). 